\title{
Cosmarium bromelicola sp. nov. (Desmidiaceae, Zygnematophyceae), a new desmid species from Northeast Brazil
}

\author{
G. J. P. Ramos ${ }^{a}$, C. E. M. Bicudo ${ }^{b}$ and C. W. N. Moura ${ }^{a}$ \\ aPrograma de Pós-graduação em Botânica, Universidade Estadual de Feira de Santana - UEFS, \\ Av. Transnordestina, s/n, CEP 44036-900, Feira de Santana, BA, Brasil

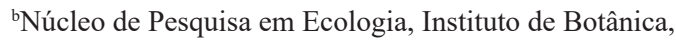 \\ Av. Miguel Estéfano, 3687, CEP 04301-902, São Paulo, SP, Brasil \\ *e-mail: geraldojpr@gmail.com
}

Received: May 31, 2017 - Accepted: December 7, 2017 - Distributed: August 31, 2019

(With 13 figures)

\begin{abstract}
Cosmarium bromelicola sp. nov. is a new desmid species described from samplings carried out in bromeliad tanks (phytotelmata) from an area of rocky outcrops at Serra da Jiboia, Bahia State, Northeast Brazil. Presence of subtrapeziform cells with a deep depression at the apical region and twisted X-shaped cell in side view are the diagnostic features for the species. Relationships with the morphologically closest taxa are discussed.
\end{abstract}

Keywords: Alcantarea nahoumii, algae, bromeliad, phytotelm.

\section{Cosmarium bromelicola sp. nov. (Desmidiaceae, Zygnematophyceae), uma nova espécie de desmídia do nordeste do Brazil}

\section{Resumo}

Cosmarium bromelicola sp. nov. é uma nova espécie de desmídia descrita a partir de amostragens realizadas em tanques de bromélias (fitotelmata) de uma área de afloramentos rochosos na Serra da Jiboia, Bahia, nordeste do Brasil. A presença de células trapeziformes com uma depressão profunda na região apical e célula em forma de X em vista lateral são as características diagnósticas da espécie. Relações com os táxons morfologicamente próximos são discutidas.

Palavras-chave: Alcantarea nahoumii, algas, bromélias, fitotelmo.

\section{Introduction}

Phytotelmata are aquatic habitats formed by vegetal structures capable of maintaining several associated organisms, including algae (Varga, 1928; Kitching, 2000). Among the major algal groups inhabiting the bromeliad phytotelmata are the desmids, especially Cosmarium Corda ex Ralfs considered the largest desmid genus in terms of number of species (over 2,000), and one of the oldest names among the placoderm desmids (Prescott et al., 1981; Sophia et al., 2004; Bicudo and Menezes, 2017; Brook and Johnson, 2011).

Cosmarium is characterized by having generally solitary cells, semicells rounded, reniform, pyramidate, quadrate with entire or undulate margin; subcircular to elongate-oval (biradiate) in apical view; cell wall smooth with scattered pores or ornamented; one to several chloroplasts per semicell, axial or parietal, and as well as other desmids generally inhabit acidic, oligotrophic, aquatic environments and occasionally subaerial or in basic, eutrophic water (Guiry and Guiry, 2017).
In Brazil, 157 species and 146 taxonomic varieties of Cosmarium were inventoried so far (Felisberto and Rodrigues, 2004; Oliveira et al., 2011; Menezes et al., 2015), 18 of which were reported from bromeliad phytotelmata (Ramos et al., 2018).

Present report describes a new desmid species, Cosmarium bromelicola sp. nov., collected from tanks of Alcantarea nahoumii (Leme) J.R.Grant, an endemic bromeliad from Bahia, inhabiting rocky outcrops of the Serra da Jiboia, Brazil. This bromeliad is considered a vulnerable species per the IUCN standards and usually suffer with burning and extraction, as well as other threats (Forzza et al., 2013).

\section{Material and Methods}

"Serra da Jiboia" is located in the South "Recôncavo", i.e. the eastern part of Bahia State, Brazil, made up by a complex of small hills (Pioneira, Oiti, Monte Cruzeiro, Água Branca, etc.) occupying an area of approximately 22,500 ha at the maximum altitude of $850 \mathrm{~m}$ above the 
sea level. The South "Recôncavo" region is located at the outskirts of the Atlantic Forest and the Semi-Arid Domains. Local vegetation includes plants inhabiting granitic rocky outcrops of the top, tropical rain forest on the east slope, and "Caatinga" on the west and north (Juncá and Borges, 2002).

Eighty samples were collected during January, July, September and November 2015 (20 in each month) in tanks of Alcantarea nahoumii (Bromeliaceae), at the top of "Monte da Pioneira" (Santa Teresinha municipality), with the aid of a $50 \mathrm{~mL}$ syringe coupled on a polyethylene hose. Water abiotic information such as temperature, $\mathrm{pH}$, and conductivity, was measured using a Hanna multiparameter probe. After collection, part of the samples was kept alive for two weeks at $25^{\circ} \mathrm{C}$ in the UEFS Phycology Laboratory for morphological observations, and the other part preserved with Transeau solution (Bicudo and Menezes, 2017). All the samples collected were registered on Herbarium of the State University of Feira de Santana (HUEFS).

Morphological features and cell dimensions of the specimens were derived from light microscope (LM) (Olympus Model BX 43) observations. A population of about 100 individuals was analyzed which allowed a detailed examination of their morphological features.

The images were captured with a digital camera (5.0 MP QImaging) using the Image-Pro Premier 9.1.4 software. First step before starting the SEM protocol was the addition of a $2 \%$ CTAB solution during $24 \mathrm{~h}$ to remove the excess of mucilage surrounding the cells (Tavera and Calderón, 2013). To study more details of cell wall we prepare SEM samples adapting the protocol from Van Westen (2015) for desmids (acetone series: 30\%, 50\%, 70\%, 85\%, 95\%, $100 \%, 100 \%)$.

\section{Results}

\subsection{Taxonomic account}

Cosmarium bromelicola G.J.P.Ramos, C.E.M.Bicudo and C.W.N.Moura, sp. nov. (Figures 1-13).

Cells solitary, as long as broad, median constriction deep, sinus linear, narrow, expanded near the isthmus; semicell subtrapeziform, apical view elliptic with a central, deep median depression, side view subpyramidal, focused internally has X-shaped similar to a chromosome, lateral margins divergent towards the apex; cell wall granulate, with rows of well-marked pits (scrobicle), each of them bearing a distinct pore, lateral margin granulate; chloroplast axial, 2 pyrenoids per semicell. Zygospore unknown. Cell dimensions: 50-63 $\mu \mathrm{m}$ length, 50-61.4 $\mu \mathrm{m}$ breadth, 17.5-21.6 $\mu \mathrm{m}$ isthmus.

\subsection{Differential diagnosis}

Cosmarium bromelicola differs from all other species of the genus by having subtrapeziform semicells with a central median depression at the apical region, and subpyramidal in side view, when focused internally is $\mathrm{X}$-shaped, like a chromosome

\subsection{Habitat}

Bromeliad tanks (Alcantarea nahoumii); water temperature 21.7-31 ${ }^{\circ} \mathrm{C}$; $\mathrm{pH}$ 4.3-6.6; conductivity 0.05-0.65 mS.cm ${ }^{-1}$.

\subsection{Material examined}

Brazil, Bahia, Santa Teresinha, Serra da Jiboia, 1251'07.1”'S, 39²8'36.0”' W, 20/11/2015, G.J.P. Ramos, C.W.N. Moura and C.A. Ribeiro S.n. (Holotype: HUEFS 220176!). Paratypes: HUEFS 155295, 224653, 224654, 224658, 224661, 224666, 224673, 224676, 224686, 224687, 224688, 224693, 224698, 224712, 224716, 224724, 224728.

\subsection{Etymology}

The epithet is derived from bromeliad, plant which the species inhabit.

\section{Discussion}

Cosmarium bromelicola has a unique morphology among all Cosmarium species, i.e. the presence of a usually deep depression at the apical region of cell that gives the semicell the shape of a bowl in the front view. In addition, when the cell is focused in side view, the X-shaped look like a chromosome, also a distinctive pattern among the other Cosmarium species.

Although easily identifiable through the above features, C. bromelicola can be somewhat confused with Cosmarium species with subtrapeziform semicells as $C$. biretum Brebisson ex Ralfs and C. latifrons P.Lundell. Cosmarium biretum differs from $C$. bromelicola by having semicells elliptical, with a visible protuberance at the mid of the apical view, and the subcircular-ovoid semicells in the side view. In other hand, C. latifrons is distinct from C. bromelicola in the smaller elliptical semicells with a 3-granular median protuberance in apical view and the ovoid side view. In addition, limited geographic distribution of Cosmarium latifrons to the temperate and polar regions (Prescott et al., 1981) can also be used for its distinction from C. bromelicola.

Due to this apical depression, this species can be also easily confused with collapsed cells of some Cosmarium species, mainly those possessing a fragile cell wall. However, the occurrence of collapsed cells does not apply to $C$. bromelicola because the apical depression was present in all specimens analyzed, with the same pattern observed in living populations, i.e. this morphology, in this case, does not due to be related to over-strength preservative. Other desmids also were described having apical concavity as Vincularia roraimae K. Fučíková and J.Kaštovský, which was found from various types of habitats in top of Mont Roraima (Fučíková and Kaštovský, 2009).

Cosmarium bromelicola is probably a rather susceptible species to environmental changes when compared with other Cosmarium species present in the A. nahoumii tanks in the area, such as $C$. elegantissimum P.Lundell and C. pseudoconnatum Nordstedt. We observed that the latter was kept alive for two weeks, but C. bromelicola easily lost the natural features of its chloroplast after a short period (1-2 days), giving the cells with a senescent look (brown color). This phenomenon happened during 

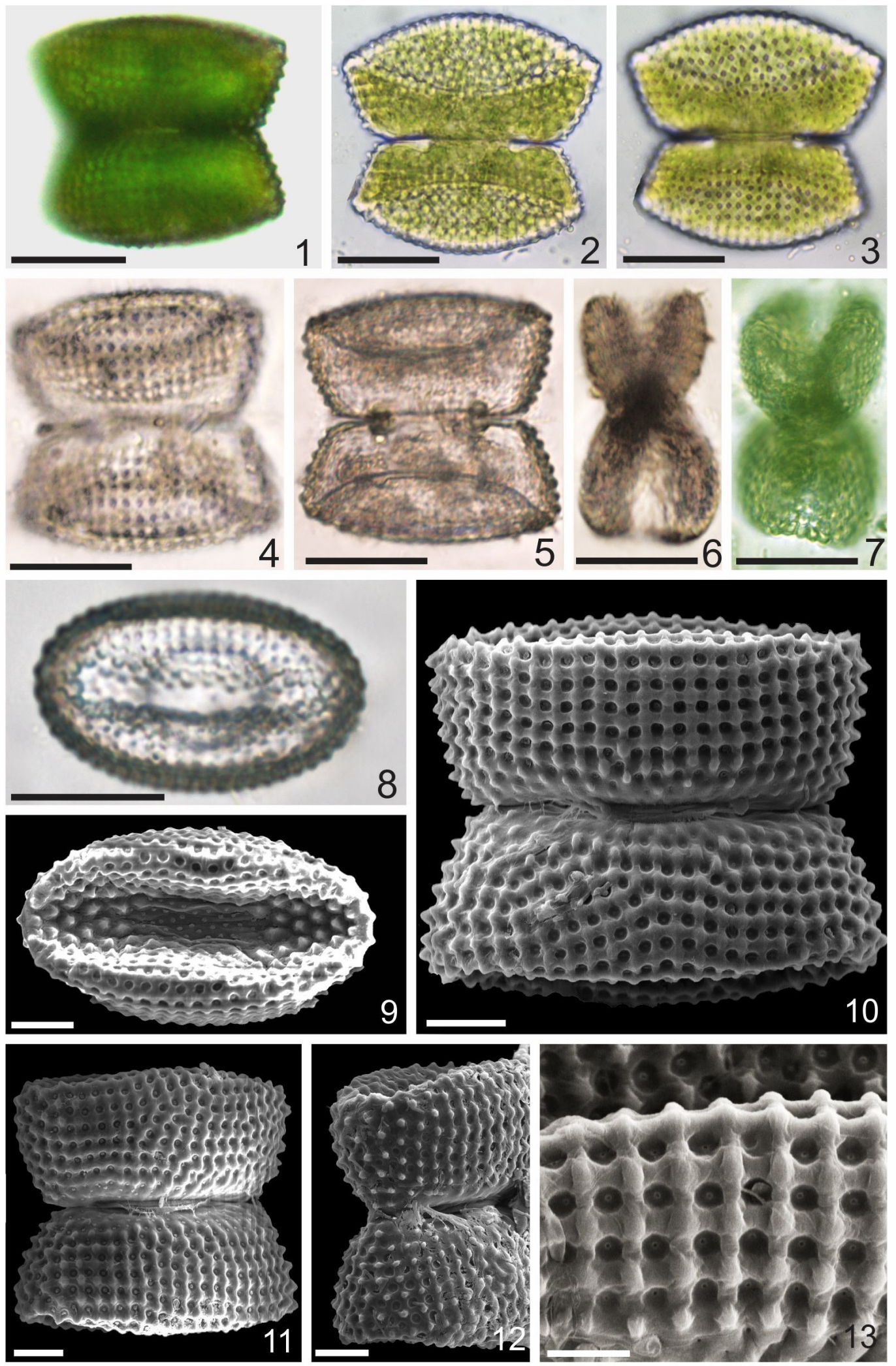

Figures 1-13. Cosmarium bromelicola sp. nov. 1-8. LM images. 1-5. Front view. 6-7. Side view. 8. Apical view. 9-13. SEM images. 9. Apical view. 10-11. Front view. 12. Side view. 13. Detail of cell wall pores. Scale Bars $=30 \mu \mathrm{m}(1-8),=10 \mu \mathrm{m}$ $(9-13)$. 
the four months' period in which the samples were collected. Cosmarium bromelicola occurred in 18 from a total of 80 samples collected and zygospores were not found. Finally, further phycological studies are needed, not only in bromeliads, but also in other plants capable to form phytotelmata.

\section{Acknowledgements}

The authors are grateful to CNPq, Conselho Nacional de Desenvolvimento Científico e Tecnológico and FAPESB, Fundação de Amparo à Pesquisa do Estado da Bahia (Projeto Flora da Bahia, 483909/2012) for financial support. The authors also thank the support of the "Serviço de Microscopia Eletrônica" of CPqGM of the technological facilities of FIOCRUZ for SEM studies. GJPR thanks to FAPESB for Doctoral fellowship (nº BOL0513/2014).

\section{References}

BICUDO, C.E.M. and MENEZES, M., 2017. Gêneros de algas de águas continentais do Brasil: chave para identificação e descrições. 3rd ed. São Carlos: Rima, 552 p.

BROOK, A.J. and JOHNSON, L.R., 2011. Phylum Chlorophyta: Order Zygnematales [excl. Zygnemataceae]. In: D.M. JOHN, B.A. WHITTON and A.J. BROOK, eds. The freshwater algal flora of the British Isles: an identification guide to freshwater and terrestrial algae. Cambridge: Cambridge University Press, pp. 576-608.

FELISBERTO, S.A. and RODRIGUES, L., 2004. Periphytic desmids in Corumbá reservoir, Goiás, Brazil: genus Cosmarium Corda. Brazilian Journal of Biology $=$ Revista Brasileira de Biologia, vol. 64, no. 1, pp. 141-150. http://dx.doi.org/10.1590/ S1519-69842004000100016. PMid:15195373.

FORZZA, R.C., COSTA, A.F., LEME, E.M.C., VERSIEUX, L.M., WANDERLEY, M.G.L., LOUZADA, R.B., MONTEIRO, R.F., JUDICE, D.M., FERNANDEZ, E.P., BORGES, R.A.X., PENEDO, T.S.A., MONTEIRO, N.P. and MORAES, M.A., 2013. Bromeliaceae. In: G. MARTINELLI and M.A. MORAES, eds. Livro vermelho da Flora do Brasil. Rio de Janeiro: Jardim Botânico do Rio de Janeiro, pp. 315-396.

FUČÍKOVÁ, K. and KAŠTOVSKÝ, J., 2009. Vincularia roraimae (Zygnematophyceae, Desmidiales), gen. et sp. nov. from the top of Mt. Roraima, Venezuela. Nova Hedwigia, vol. 88, no. 1, pp. 49-56. http://dx.doi.org/10.1127/0029-5035/2009/0088-0049.

GUIRY, M.D. and GUIRY, G.M., 2017 [viewed 4 April 2017]. AlgaeBase [online]. Galway: National University of Ireland. Available from: http://www.algaebase.org

JUNCÁ, F.A. and BORGES, C.L.S., 2002. Fauna associada a bromélias terrícolas da Serra da Jiboia, Bahia. Sitientibus, Série Ciências Biológicas, vol. 2, no. 1-2, pp. 73-81.
KITCHING, R.L., 2000. Food webs and container habitats: the natural history and ecology of Phytotelmata. Cambridge: Cambridge University Press, 429 p. http://dx.doi.org/10.1017/ CBO9780511542107.

MENEZES, M., BICUDO, C.E.M., MOURA, C.W.N., ALVES, A.M., SANTOS, A.A., PEDRINI, A.G., ARAÚJO, A., TUCCI, A., FAJAR, A., MALONE, C., KANO, C.H., SANT'ANNA, C.L., BRANCO, C.Z., ODEBRECHT, C., PERES, C.K., NEUHAUS, E.B., ESKINAZI-LEÇA, E., AQUINO, E., NAUER, F., SANTOS, G.N., AMADO FILHO, G.M., LYRA, G.M., BORGES, G.C.P., COSTA, I.O., NOGUEIRA, I.S., OLIVEIRA, I.B., PAULA, J.C., NUNES, J.M.C., LIMA, J.C., SANTOS, K.R.S., FERREIRA, L.C., GESTINARI, L.M.S., CARDOSO, L.S., FIGUEIREDO, M.A.O., SILVA, M.H., BARRETO, M.B.B.B., HENRIQUES, M.C.O., CUNHA, M.G.G.S., BANDEIRA-PEDROSA, M.E., OLIVEIRA-CARVALHO, M.F., SZÉCHY, M.T.M., AZEVEDO, M.T.P., OLIVEIRA, M.C., CABEZUDO, M.M., SANTIAGO, M.F., BERGESH, M., FUJII, M.T., BUENO, N.C., NECCHI JUNIOR, O., JESUS, P.B., BAHIA, R.G., KHADER, S., ALVES-DA-SILVA, S.M., GUIMARÃES, S.M.P.B., PEREIRA, S.M.B., CAIRES, T.A., MEURER, T., CASSANO, V., WERNER, V.R., GAMA JUNIOR, W.A. and SILVA, W.J., 2015. Update of the Brazilian floristic list of Algae and Cyanobacteria. Rodriguésia, vol. 66, no. 4, pp. 1047-1062. http://dx.doi.org/10.1590/2175-7860201566408.

OLIVEIRA, I.B., BICUDO, C.E.M. and MOURA, C.W.N., 2011. New records of Cosmarium (Desmidiaceae) to Brazil. Phytotaxa, vol. 26, no. 1, pp. 25-38. http://dx.doi.org/10.11646/ phytotaxa.26.1.5.

PRESCOTT, G.W., CROASDALE, H.T., VINYARD, W.C. and BICUDO, C.E.M., 1981. A synopsis of North American desmids: part II. Desmidiaceae: Placodermae: section 3. Lincoln: University of Nebraska Press.

RAMOS, G.J.P., BICUDO, C.E.M. and MOURA, C.W.N., 2018. Some new, rare and interesting desmids from bromeliad phytotelmata in Brazil. Phytotaxa, vol. 346, no. 1, pp. 59-77. https://doi.org/10.11646/phytotaxa.346.1.3.

SOPHIA, M.G., CARMO, B.P. and HUSZAR, V.L., 2004. Desmids of phytotelm terrestrial bromeliads from the National Park of "Restinga de Jurubatiba", Southeast Brasil. Archiv für Hydrobiologie. Supplementband, Algological Studies, vol. 114, no. 1, pp. 99-119.

TAVERA, R. and CALDERÓN, E., 2013. Use of CTAB as a cost-effective solution to an old problem: the interference of the mucilage of desmids for scanning electron microscopy. Phycologia, vol. 52, no. 5, pp. 1-5. http://dx.doi.org/10.2216/13-133.1.

VAN WESTEN, M., 2015. Taxonomic notes on desmids from the Netherlands. Phytotaxa, vol. 238, no. 3, pp. 230-242. http:// dx.doi.org/10.11646/phytotaxa.238.3.2.

VARGA, L., 1928. Ein interessanter Biotop der Biocönose von Wasserorganismen. Biologisches Zentralblatt, vol. 48, pp. 143-162. 